\title{
K-Ar ages of seamounts along the Japan Trench and the effect of acid leaching on the K-Ar age of a dredged submarine rock
}

\author{
ICHIRO KANEOKA \\ Geophysical Institute, University \\ of Tokyo, Tokyo, Japan* \\ (Received May 21, 1971)
}

\begin{abstract}
The ages of submarine rocks dredged from seamounts along the Japan Trench were determined by $\mathrm{K}-\mathrm{Ar}$ method.

In order to obtain more reliable age, the effect of acid leaching on an altered submarine rock was examined. Some samples treated by acid solution gave K-Ar ages up to $20 \%$ older than the original untreated sample. This result suggests a possibility that, if suitable acid teratment conditions are found, they would result in more reliable ages for submarine rocks.

Some submarine rocks dredged from seamounts along the Japan Trench on the oceanic side gave K-Ar ages of about 70-80 m.y, whereas a sample dredged from a seamount on the Japanese Islands side gave a substantially younger age. Considering the present result as well as previous data, the last volcanic activity along the Japan Trench seems to have occurred about $70-80$ m.y ago or older.
\end{abstract}

\section{INTRODUCTION}

The Northwestern Pacific floor is reported to be one of the oldest areas in the Pacific (EwING et al., 1966). Further heat flow measurements in this area indicate relatively low value (VACQUIER et al., 1966) and the fact that islands are very few in this area may be related with its lack of volcanic activity in recent years together with the subsidence of the area (KANEOKA). However along the Japan Trench, many seamounts are observed. Since seamounts are considered to be formed after the formation of the ocean floor, their ages would suggest the period of later volcanic activities within the area. Hence, in connection with the mechanism of the formation of the area, it is very significant to know the period of the last volcanic activities within the area. For this purpose, K-Ar ages were determined for some submarine rocks dredged from seamounts along the Japan Trench.

In the K-Ar dating of dredged submarine rocks, the presence of excess argon

* Present address: Max-Planck-Institut für Kernphysik, Heidelberg, Germany 
(DAlrymple and MoORe, 1968; Funkhouser et al., 1968; Noble and Naughton, 1968) and the alteration of dredged rocks cause some problems. However, as long as the innermost part of a relatively old crystalline volcanic rock is used, the effect of excess argon would not be serious for the measured age (OzIma et al., 1970a).

On the other hand, such old dredged submarine rocks are commonly altered due to contact with sea water. During this process, radiogenic argon would be lost from the rocks and secondary clay minerals may preserve a high $\mathrm{K}$ content, thus reducing the apparent $\mathrm{K}$-Ar ages. These $\mathrm{K}-\mathrm{Ar}$ ages should therefore be regarded as minimum ages if the effect of excess argon is negligible.

In order to obtain reliable $\mathrm{K}$-Ar ages for submarine rocks, it is necessary to get unaltered rocks whose glass content is low. However, it is not always possible to do so and for older rocks the situation becomes more difficult. Furthermore the number of dredged rocks at a site is limited. Hence it is desirable to find a suitable way to get more reliable ages even for altered rocks.

Acid leaching treatment of a dredged, altered rock was carried out and the effects on the K-Ar ages were examined. It was anticipated that by using a suitable acid solution, some kind of secondary clay minerals might be dissolved selectively; the resultant $\mathrm{K}-\mathrm{Ar}$ age would then become closer to the true formation age.

\section{EXPERIMENTAL}

\section{$K$ and Ar analyses}

Potassium was analyzed with a Baird-Atomic two channel flame photometer with a $500 \mathrm{ppm} \mathrm{Li}$ internal standard and a $1250 \mathrm{ppm} \mathrm{Na}$ buffer. Argon analyses were made by isotope dilution with an argon- 38 tracer, using a $15 \mathrm{~cm}$ radius pyrex-tube mass spectrometer. Analytical uncertainty in $\mathrm{K}$ and $\mathrm{Ar}$ analyses is about 2 percent for each. More details about the $\mathrm{K}$ and $\mathrm{Ar}$ analysis procedures are described elesewhere (OzIma et al., 1968).

\section{Acid leaching treatment}

The rock (JT 1-55) selected for acid leaching treatment was dredged from the top of the 'Daini-Kashima' seamount $\left(36^{\circ} 04^{\prime} \mathrm{N}, 143^{\circ} 32^{\prime} \mathrm{E}\right)$. It is a basalt (or andesite) and the phenocrysts and the groundmass are altered, except for the phenocryst of plagioclase, which remains fresh. Secondary minerals such as montmorillonite and zeolite are observed.

Solutions of $12 \mathrm{~N}$ hydrochloric acid, $2.5 \mathrm{~N}$ hydrochloric acid, $0.95 \mathrm{~N}$ sodium carbonate and $12 \%$ hydrofluoric acid were prepared. 20-60 mesh samples of the rock were immersed in each acid solution for 20 hours at room temperature. One sample was only rinsed 20 times with distilled water on the grounds that some clay minerals attached to other grain surface might be removed by this procedure (Table 1). K and $\mathrm{Ar}$ analyses were made for these samples (Table 2). 
Table 1. Conditions for acid leaching treatment

\begin{tabular}{cclcc}
\hline \hline Sample & $\begin{array}{c}\text { Grain Size } \\
(\text { mesh) }\end{array}$ & \multicolumn{1}{c}{ Solution } & $\begin{array}{c}\text { Temperature } \\
\left({ }^{\circ} \mathrm{C}\right)\end{array}$ & $\begin{array}{c}\text { Leaching } \\
\text { Time (hr) }\end{array}$ \\
\hline A & $-20+60$ & not used & - & - \\
B & $-20+60$ & $12 \mathrm{~N} \mathrm{HCl}$ & 25 & 20 \\
C & $-20+60$ & $2.5 \mathrm{~N} \mathrm{HCl}$ & 25 & 20 \\
D & $-20+60$ & $0.95 \mathrm{~N} \mathrm{Na}_{2} \mathrm{CO}_{3}$ & 25 & 20 \\
E & $-20+60$ & $12 \% \mathrm{HF}$ & 25 & 20 \\
F & $-20+60$ & not used, & - & - \\
& & rinsed with & & \\
\hline
\end{tabular}

Rock: JT 1-55, altered basalt (or andesite) dredged from the 'Daini-Kashima' seamount $\left(36^{\circ} 04^{\prime} \mathrm{N}, 143^{\circ} 32^{\prime} \mathrm{E}\right)$.

Table 2. Effect of acid leaching treatment on the K/Ar ages of dredged submarine rocks (JT 1-55)

\begin{tabular}{cccccc}
\hline \hline Sample & $\begin{array}{c}\left({ }^{40} \mathrm{Ar}\right) \mathrm{rad} \\
(\mathrm{mole} / \mathrm{g})\end{array}$ & $\begin{array}{c}\frac{\left({ }^{40} \mathrm{Ar}\right) \text { air }}{\left({ }^{40} \mathrm{Ar}\right) \text { tot }} \\
(\%)\end{array}$ & $\begin{array}{c}(\mathrm{K}) \\
(\%)\end{array}$ & $\frac{\left({ }^{40} \mathrm{Ar}\right) \mathrm{rad}}{\left({ }^{40} \mathrm{~K}\right)}$ & $\begin{array}{c}\text { Age* } \\
(\mathrm{m} . \mathrm{y})\end{array}$ \\
\hline $\mathrm{A}$ & $3.409 \times 10^{-10}$ & 16.7 & $2.86 \pm 0.01$ & $3.927 \times 10^{-3}$ & $66.0 \pm 1.3$ \\
$\mathrm{~B}$ & $3.481 \times 10^{-10}$ & 9.5 & $2.66 \pm 0.08$ & $4.304 \times 10^{-3}$ & $72,2 \pm 1.4$ \\
$\mathrm{C}$ & $3.822 \times 10^{-10}$ & 15.3 & $2.61 \pm 0.07$ & $4.817 \times 10^{-3}$ & $80.6 \pm 1.6$ \\
$\mathrm{D}$ & $3.022 \times 10^{-10}$ & 16.2 & $2.52 \pm 0.05$ & $3.945 \times 10^{-3}$ & $66.3 \pm 1.3$ \\
$\mathrm{E}$ & $3.094 \times 10^{-10}$ & 27.6 & $2.55 \pm 0.07$ & $3.991 \times 10^{-3}$ & $67.0 \pm 1.4$ \\
$\mathrm{~F}$ & $3.473 \times 10^{-10}$ & 31.1 & $2.60 \pm 0.02$ & $4.394 \times 10^{-3}$ & $73.7 \pm 1.6$ \\
\hline \multicolumn{5}{c}{$*$} & $\lambda \mathrm{e}=0.585 \times 10^{-10} \mathrm{y}^{-1}, \lambda_{\beta}=4.72 \times 10^{-10} \mathrm{y}^{-1},{ }^{40} \mathrm{~K} / \mathrm{K}=1.19 \times 10^{-4} \mathrm{~mole} / \mathrm{mole}$. \\
\\
Error indicates one standard deviation.
\end{tabular}

\section{RESULTS AND DISCUSSION}

\section{Acid leaching treatment}

The apparent K-Ar age of the unleached whole rock (JT 1-55) is $66 \mathrm{~m} . \mathrm{y}$, whereas the acid leached samples sometimes give older ages. All samples treated by acid leaching show lower $\mathrm{K}$ content than the original whole rock (Table 2). Since some secondary minerals may contain relatively high potassium (e.g. montmorillonite), they will cause the apparent $\mathrm{K}-\mathrm{Ar}$ age to be less than the true age. Using the acid solution, some of the secondary minerals are dissolved and the primary minerals are relatively enriched.

In Table 2 , it is noteworthy that the sample treated with $2.5 \mathrm{~N}$ hydrochloric acid solution shows a K-Ar age of about $81 \mathrm{~m} . \mathrm{y}$, which is more than 20 percent older than the age of original whole rock. Even the sample which was only rinsed with distilled water indicates a K-Ar age more than 10 percent older than the original whole rock. In this case, some secondary minerals on the surface of each grain are removed by rinsing with water.

In the case of the samples treated with $12 \mathrm{~N}$ hydrochloric acid solution and $0.95 \mathrm{~N}$ 
sodium carbonate solution, the resultant K-Ar ages are almost the same as that of the original whole rock, though their K contents are also lowered. Such solutions may affect the primary minerals, and be not useful for the present purpose.

In the present study, the conditions for acid treatment were determined rather arbitrally. If more suitable conditions are established, more reliable K-Ar age may be determined even for altered submarine rocks.

\section{$K$-Ar ages of seamounts along the Japan Trench}

$\mathrm{K}$-Ar ages of submarine rocks dredged from the top of seamounts along the Japan Trench were determined and the results are shown in Table 3.

Table 3. K-Ar ages of dredged submarine rocks from the Northwestern

Pacific along the Japan Trench

\begin{tabular}{|c|c|c|c|c|c|c|c|c|}
\hline Sample* & $\begin{array}{l}\text { Dredging } \\
\text { Locality }\end{array}$ & $\begin{array}{l}\text { Dredging } \\
\text { Depth } \\
\text { (m) }\end{array}$ & Rock Name & $\begin{array}{c}\left({ }^{40} \mathrm{Ar}\right) \mathrm{rad} \\
(\mathrm{moles} / \mathrm{gm})\end{array}$ & 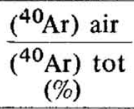 & $\begin{array}{l}(\mathrm{K}) \\
(\%)\end{array}$ & $\frac{\left({ }^{40} \mathrm{Ar}\right) \mathrm{rad}}{\left({ }^{40} \mathrm{~K}\right)}$ & $\begin{array}{l}\text { Age** } \\
\text { (m.y) }\end{array}$ \\
\hline $\begin{array}{c}\text { JT } 1-55 \\
\text { (w.r.) }\end{array}$ & $\begin{array}{r}36^{\circ} 04^{\prime}, \mathrm{N} \\
143^{\circ} 32^{\prime} \mathrm{E}\end{array}$ & $3,350-3,700$ & $\begin{array}{l}\text { Basalt (or } \\
\text { andesite) }\end{array}$ & $3.409 \times 10^{-10}$ & 16.7 & $2.86 \pm 0.06$ & $3.927 \times 10^{-3}$ & $66.0 \pm 1.3$ \\
\hline $\begin{array}{l}\text { JT } 5 \\
\text { (w.r.) }\end{array}$ & $\begin{array}{r}37^{\circ} 07^{\prime} \mathrm{N} \\
145^{\circ} 18^{\prime} \mathrm{E}\end{array}$ & $2,200-2,630$ & Andesite (?) & $3.159 \times 10^{-10}$ & 33.8 & $2.51 \pm 0.03$ & $4.140 \times 10^{-3}$ & $69.5 \pm 1.5$ \\
\hline $\begin{array}{c}\text { JT } 8-12 \\
\text { (w.r.) }\end{array}$ & $\begin{array}{r}39^{\circ} 37^{\prime} \mathrm{N} \\
143^{\circ} 43^{\prime} \mathrm{E}\end{array}$ & $3,050-3,100$ & $\begin{array}{l}\text { Hy persthene- } \\
\text { augite } \\
\text { andesite }\end{array}$ & $2.845 \times 10^{-10}$ & 20.8 & $3.21 \pm 0.01$ & $2.915 \times 10^{-3}$ & $49.2 \pm 1.0$ \\
\hline $\begin{array}{l}\text { JT } 18-20 \\
\text { (w.r.) }\end{array}$ & $\begin{array}{r}40^{\circ} 57^{\prime} \mathrm{N} \\
144^{\circ} 54^{\prime} \mathrm{E}\end{array}$ & $3,950-4,200$ & Andesite & $2.969 \times 10^{-10}$ & 31.6 & $2.03 \pm 0.02$ & $4.822 \times 10^{-3}$ & $80.7 \pm 1.7$ \\
\hline $\begin{array}{l}\text { G205-1-202 } \\
\text { (f.p.) }\end{array}$ & $\begin{array}{r}40^{\circ} 54^{\prime} \mathrm{N} \\
144^{\circ} 50^{\prime} \mathrm{E}\end{array}$ & 4,000 & $\begin{array}{l}\text { Olivine- } \\
\text { titanaugite } \\
\text { basalt }\end{array}$ & $1.881 \times 10^{-10}$ & 34.9 & $1.34 \pm 0.03$ & $4.673 \times 10^{-3}$ & $78.2 \pm 1.6$ \\
\hline
\end{tabular}

* w.r. : whole rock, f.p. : felsic part excluding plagioclase.

** $\lambda \mathrm{e}=0.585 \times 10^{-10} \mathrm{y}^{-1}, \lambda_{\beta}=4.72 \times 10^{-10} \mathrm{y}^{-1},{ }^{40} \mathrm{~K} / \mathrm{K}=1.19 \times 10^{-4} \mathrm{~mole} / \mathrm{mole}$.

Error indicates one standard deviation.

For the dredged rocks from the 'Daini-Kashima' seamount (JT 1-55), the K-Ar age obtained after $2.5 \mathrm{~N}$ hydrochloric acid solution treatment is more reliable than that of the untreated whole rock age, and the value of $81 \mathrm{~m} . \mathrm{y}$ is regarded as the K-Ar age of the dredged rocks from the 'Daini-Kashima' seamount.

The sample JT 5 is much altered and the result is considered to show its minimum age, whereas the sample JT 8-12 and JT 18-20 are relatively fresh and though the results may also show the minimum age, the values may be not much different from the true ages of formation.

A K-Ar isochron plot can be made for the sample G205-1-202, from the present result together with data reported previously (OzImA et al., 1970b), (Fig.1). The three points lie on an isochron of $79 \mathrm{~m} . \mathrm{y}$, which goes through the zero point, indicating that excess argon is negligible in this sample. This age is concordant with the estimated age of Upper Cretaceous from paleontological evidence (TsUCHI and KAGAMI, 


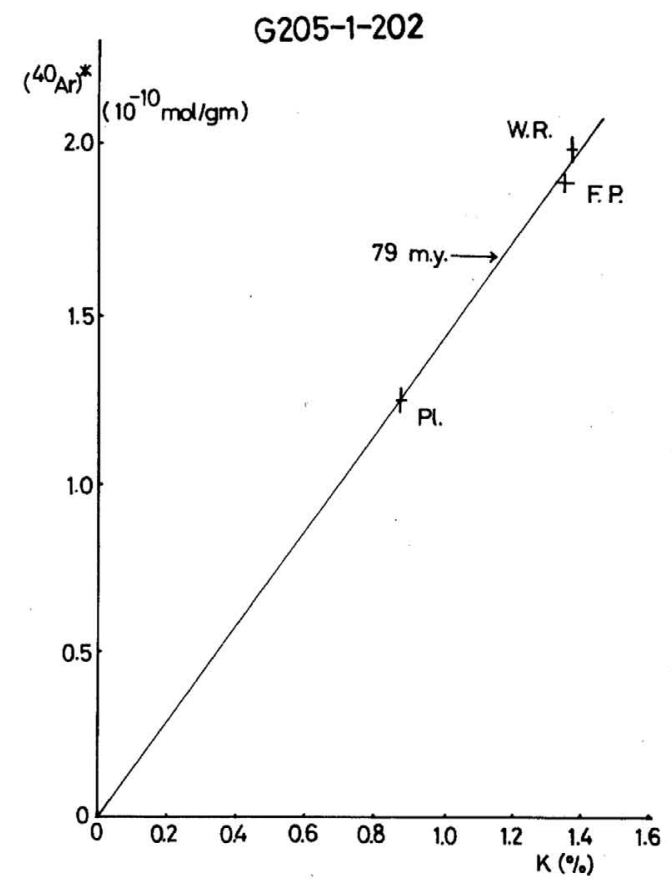

Fig.1. K-Ar isochron plot for the sample G2051-202. W.R.; whole rock, Pl; plagioclase, F.P.; felsic part excluding plagioclase.

1967).

In Fig. 2, the results of the K-Ar ages of dredged submarine rocks along the Japan Trench area are summarized. It is shown that most of them are concentrated in the age range of 70-80 m.y. Since they are altered to some degrees, these ages are considered to show the minimum age of the last volcanic activities in this area.

In general, it is considered that a seamount is formed within the area after the formation of the ocean floor or at least has approximately the same age as the ocean floor. Hence the age of the ocean floor around this area is older than 70-80 m.y. The comparatively old ages of the last volcanic activities within the area are consistent with the result of low heat flow data (VACQuiER et al., 1966).

As shown in Fig.2, the K-Ar ages of seamounts show no systematic variation with their sites and the last activities of the seamounts along the Japan Trench is 70-80 m.y or older. However one sample dredged from the west side of the Japan Trench shows younger age of about $50 \mathrm{~m} . \mathrm{y}$ (JT 8-12). Since this sample is not so altered as the samples JT 1-55 and JT 5, this younger age is meaningful in considering the mechanism of the formation of the seamount, and it may indicate some volcanic activities of the Japanese Islands in this area. 


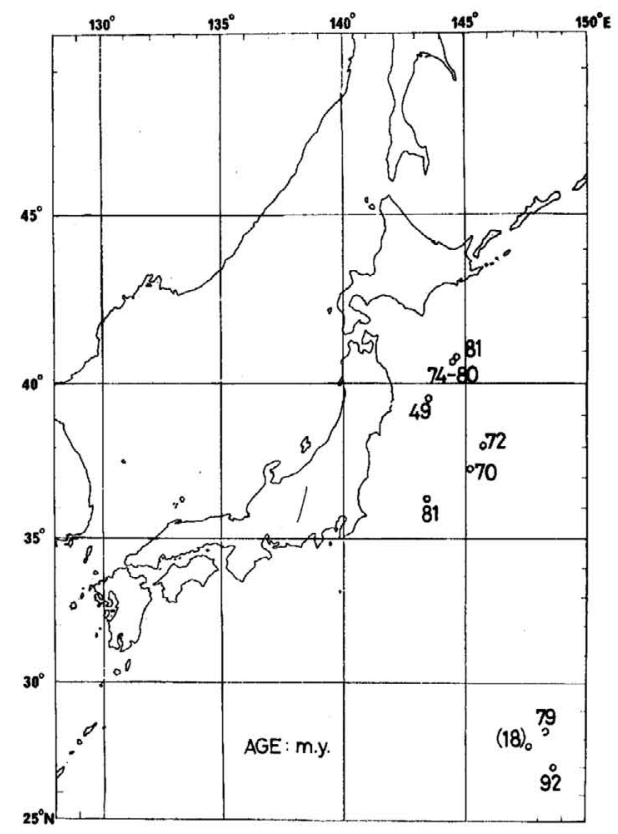

Fig.2. K-Ar ages of seamounts along the Japan and the Bonin Trenches. Data sources; OzIMA et al. (1970b) and the present work. A plot in the parenthesis indicates an unreliable value due to the strong alteration of the rock.

\section{CONCLUSIONS}

(1) Some acid leaching treatments for altered submarine rocks seem to dissolve selectively the secondary clay minerals, and the K-Ar ages of the samples treated by acid leaching become higher than that of the original whole rock. Hence if suitable acid leaching conditions are found, more reliable $\mathrm{K}$-Ar age can be determined for submarine rocks.

(2) The K-Ar ages of the seamounts on the east side of the Japan Trench indicate that the end of the last volcanic activities was about 70-80 m.y ago, whereas on the west side of the Japan Trench, a comparatively younger rock age of about $50 \mathrm{~m} . \mathrm{y}$ is determined. This difference may be related to the mechanism of formation of these seamounts.

\section{ACKNOWLEDGMENTS}

The author is much grateful to Prof. R. D. RuSSELL for reading the original manuscript. He also expresses his sincere thanks to Dr. S. ARAMAKI who made the microscopic observations in the 
appendix. Thanks are due to Drs. M. OzIMA, A. IIJIMA and N. SHIMIZU for giving helpful suggestions on this work.

Samples used in this study were generously provided by Dr. H. KINOSHITA and K analyses were made by Mr. S. ZASHU, to whom the author is much indebted.

\section{REFERENCES}

DALRYMPLE, G. B. and MoORE, J. G. (1968) Argon-40: excess in submarine pillow basalts from Kilauea volcano, Hawaii. Science 161, 1132-1135.

EwING, M., SAITo, T., EwING, J. T. and BURCKLE, L. H. (1966) Lower Cretaceous sediments from the northwest Pacific. Science 152, 751-755.

FunkHouser, J. G., FISHER, D. E. and BonATTI, E. (1968) Excess argon in deep sea rocks. Earth Planet. Sci. Lett. 5, 95-100.

KANEOKA, I., An evidence of subsidence of seamounts in the Northwestern Pacific. Mar. Geophys. Res. (in press).

Noble, C. S. and Naughton, J. J. (1968) Deep ocean basalts: inert gas content and uncertainties in age dating. Science 162, 265-267.

Ozima, M., OzIMA, M. and KANEOKA, I. (1968) Potassium-argon ages and magnetic properties of some dredged submarine basalts and their geophysical implications. J. Geophys. Res. 73, $711-723$.

OzImA, M., KANEOKA, I. and ARAMAKI, S. (1970a) Reply to the comments by D. E. Fisher. Earth Planet. Sci. Lett. 9, 311-312.

OzIMA, M., KANEOKA, I. and ARAMAKI, S. (1970b) K-Ar ages of submarine basalts dredged from seamounts in the western Pacific area and discussion of oceanic curst. ibid. 8, $237-249$.

TsuchI, R. and KaGami, H. (1967) Discovery of Nerineid Gastropoda from seamounts CbocoeB (Erimo) at the junction of Japan and Kuril-Kamchatka Trenches. Res. Ocean. Works Japan 9, $1-5$.

Vacquier, V., Uyeda, S., Yasui, M., Sclater, J. G., Corry, C. E. and Watanabe, T. (1966) Heat flow measurements in the northwestern Pacific. Bull. Earthquake Res. Inst. Univ. Tokyo 44, 1519-1535.

\section{APPENDIX \\ Petrographic Description of Samples}

(by S. ARAMAKI)

JT 1-55 : Altered basalt or andesite. Olivine phenocrysts completely altered. Glassy(?) and oxidized groundmass. Vesicles filled with unidentified alteration products.

JT 5 : Altered andesite(?). Abundant olivine pseudomorph. No pyroxene(?). Varioritic to trachytic texture. Cavity lined with clay minerals.

JT 8-12 : Hypersthene-augite andesite with large and abundant plagioclase phenocrysts. Vesicles filled with zeolite.

JT 18-20 : Andesite with sparse plagioclase phenocrysts. Relatively fresh. 
G205-1-202 : Olivine-titanaugite basalt. Coarse-grained. Intergranular texture. Olivine is altered, but other minerals are relatively fresh. Glass or mesostasis is poor. 